Karol MotYL

ORCID.ORG/0000-0003-4203-6434

Uniwersytet Humanistyczno-Przyrodniczy

im. Jana Dtugosza w Częstochowie

\title{
KATEGORIA CZASU \\ W BADANIACH PEDAGOGICZNYCH \\ (Z KONCEPCJĄ ANALIZY TRANSAKCYJNEJ W TLE)
}

Aвstract. Motyl Karol, Kategoria czasu w badaniach pedagogicznych (z koncepcja analizy transakcyjnej w tle) [The Category of Time in Pedagogical Research (with the Transactional Analysis as a Backdrop)]. Studia Edukacyjne nr 53, 2019, Poznań 2019, pp. 373-391. Adam Mickiewicz University Press. ISSN 1233-6688. DOI: 10.14746/se.2019.53.21

A purpose of this text is to describe how the concept of time is used in pedagogical research. An author characterizes research of educational reality in which the described category is used. Thanks to this, the potential of the concept of time was presented. The author concludes that the possibilities of this category are not used in pedagogical research and that the temporal dimension of education offers enormous exploratory possibilities. The text is completed with the characteristics of time structuring in transactional analysis as one of the ways to temporarily conceptualize interpersonal relationships in educational institutions.

Key words: time, education, research, transactional analysis, time structuring

Czymże jest czas?

Jeśli nikt mnie o to nie pyta, wiem. Jeśli pytającemu usituje wyttumaczyć, nie wiem ${ }^{1}$

Celem niniejszego tekstu jest nakreślenie możliwości eksploracyjnych, jakie daje wykorzystanie kategorii czasu w badaniach rzeczywistości edukacyjnej. Autor artykułu nie rości sobie praw do wyczerpującej charakterystyki na kilkunastu stronach całej złożoności i potencjału opisywanej kategorii analitycznej i nie przejawia również takiej intencji. Ma natomiast świadomość olbrzymiej złożoności i uniwersalności opisywanego pojęcia w szeroko ro-

\footnotetext{
${ }^{1}$ Św. Augustyn, Wyznania, przekł. Z. Kubiak, Kraków 1994, s. 266.
} 
zumianej nauce. Wszak wszystkie wydarzenia dzieją się w czasie, stąd każde badanie naukowe (w mniejszym lub większym zakresie, świadomie bądź nie, wprost lub pośrednio) do czasu się odwołuje. Opisywana kategoria może być charakteryzowana z perspektywy wielu nauk (filozofii, socjologii, psychologii, fizyki), co zapewne skutkowałoby powstaniem wielotomowego opracowania, dlatego autor tekstu ograniczy pole problemowe jedynie do charakterystyki pod kątem pedagogiki.

Według Henryki Kwiatkowskiej czas jest jedną z zaniedbanych kategorii w naukach pedagogicznych ${ }^{2}$. Podobnie uważa Jarosław Jagieła, pisząc, że

pedagogika (...) stawia pierwsze kroki w odniesieniu do problematyki czasu. Gdy sięgam pamięcią do czasów PRL-u, co najwyżej pojawiało się zagadnienie tzw. czasu wolnego uczniów. (...) Teraz tą tematyką mało kto się zajmuje. Czas wolny nabrał też innego charakteru. (...) Granica między czasem wolnym a pracą została niejako zniesiona. (...) Badania struktury i jakości wykorzystania czasu na lekcji udowadniają, że wiele czasu jest bezpowrotnie tracone ${ }^{3}$.

Agata Przybysz przeszukując polskie zasoby leksykalne pedagogiki, odnalazła dwa hasła związane z czasem: czas reakcji i czas wolny ${ }^{4}$ (choć występują także badania nad czasem w formie biografii oraz nad orientacjami temporalnymi). O ile czas reakcji będzie z reguły odnosił się do reagowania na bodziec, o tyle czas wolny jest pojęciem bardziej zróżnicowanym. W literaturze pedagogicznej pojęcie czasu wolnego definiowane jest w sposób wielowątkowy, niejednoznaczny i ujmowany w różne kategorie opisowe. Sięgając do historii, badacze wskazują na przesłanki płynące z czasów starożytnych, kiedy dla określenia czasu wolnego używano pojęcia schole. Oznaczało ono oddawanie się czynnościom przyjemnym, intelektualnym, dającym poczucie szczęścia. Platon przywoływał tu stan wolności od pracy, zobowiązań społecznych i wszelkiej konieczności. Filozof ten pod tym pojęciem rozumiał wolność własnych myśli i przekonań. Przez Arystotelesa termin schole rozumiany był jako stan umysłu intelektualnego i dobrostanu dającego szczęście. W tamtym okresie czas wolny utożsamiano także ze źródłem prestiżu (w przeciwieństwie do pracy - rodzaju degradacji społecznej). W języku łacińskim na określenie czasu wolnego używano terminu otium. Pozostawało ono w związku z greckim pojęciem schole. Opisywało ideę kształcenia własnej

${ }^{2}$ H. Kwiatkowska, Czas, miejsce, przestrzeń - zaniedbane kategorie pedagogiczne, [w:] Pedagogika u progu trzeciego tysiaclecia. Materiaty pokonferencyjne, red. A. Nalaskowski, K. Rubacha, Torun 2001, s. 57.

${ }^{3}$ J. Jagieła, A. Sarnat-Ciastko, Dlaczego analiza transakcyjna. Rozmowy o zastosowaniu analizy transakcyjnej w pracy nauczyciela i wychowawcy, Częstochowa 2015, s. 76.

4 A. Przybysz, Czas w pedagogice, [w:] Czas w życiu człowieka, red. K. Popiołek, A. Chudzicka-Czupała, Katowice 2010, s. 150. 
osobowości i własnego stylu życia. Otium symbolizowało oddzielanie tego, co wartościowe od tego, co bezwartościowe ${ }^{5}$.

Obecnie trudno zdefiniować jednoznacznie pojęcie czasu wolnego. Każde podejście definicyjne odnosi się do przyjętej metodologii. Współczesna definicja tego pojęcia precyzuje czas wolny jako zajęcia, którym jednostka może się oddawać z własnej chęci bądź dla odpoczynku, rozrywki, rozwoju swych wiadomości lub kształcenia (bezinteresownego), czy dobrowolnego udziału w życiu społecznym, po uwolnieniu się z obowiązków zawodowych, rodzinnych i społecznych ${ }^{6}$. Pojęcie to można także definiować, jako „zakres i jakość spożytkowania przez człowieka czasu, jaki ma on do wyłącznej dyspozycji"7. Jest to czas dowolnie zarządzany i przeznaczony do swobodnej decyzji po wykonaniu zadań koniecznych i obowiązkowych, którym dysponuje podmiot - osoba. Może on być poświęcony na odpoczynek psychiczny lub fizyczny, rozrywkę, bezinteresowną działalność społeczną, rozwój własnych zainteresowań, pasji i uzdolnień, czy na samowychowanie i samokształcenie $^{8}$. Omawiana problematyka należy zatem do przedmiotu badań pedagogiki czasu wolnego, która, jako dyscyplina tworząca wzory postępowania zgodnie z potrzebami jednostki, jest

nauką zdolną w każdej sytuacji do skutecznego działania, która przeciwdziała powierzchownemu kultowi rekreacji i wypoczynku, i stwarza założenia do wszelkiej działalności instytucji wczasowych ${ }^{9}$.

W rozważaniach nad edukacją istnieje także kategoria budżetu czasu. Jest to pojęcie na ogół zrozumiałe i intuicyjne. Pojęcie budżetu w znaczeniu potocznym to ogół dochodów i wydatków. Natomiast, budżet czasu można określić jako zestawienie odcinków czasu przewidzianych na realizację różnych czynności życiowych ${ }^{10}$. Głównymi składnikami budżetu czasu będą:

- zaspokojenie potrzeb fizjologicznych: sen, czynności związane z higieną osobistą, spożywanie posiłków (w domu lub poza domem), odpoczynek bierny, w tym krótki sen (drzemka);

- praca zawodowa: praca główna i dodatkowa;

${ }^{5}$ K. Kwilecki, Rozważania o czasie wolnym. Wybrane zagadnienia, Katowice 2011; Stownik grecko-polski, red. Z. Abramowiczówna, Warszawa 1965, s. 265-266.

${ }^{6}$ R. Pater, Czas wolny w (dla) edukacji kulturalnej dzieci, Edukacja Elementarna, 2015, 35, s. 12-13.

7 B. Milerski, B. Śliwerski (red.), Pedagogika. Leksykon PWN, Warszawa 2000, s. 38.

8 Tamże.

9 J. Pięta, Pedagogika czasu wolnego, Warszawa 2014, s. 187.

10 Por. Z. Kwieciński, Budżet czasu uczniów a ich środowisko, Warszawa 1979; M. Czerepaniak-Walczak, Od próżniaczenia do zniewolenia - w poszukiwaniu dyskursów czasu wolnego, [w:] Pedagogika społeczna, red. E. Marynowicz-Hetka, Warszawa 2009; J. Pięta, Pedagogika czasu wolnego, Warszawa 2014. 
- przejazdy związane z: pracą główną i dodatkową, zajęciami domowymi i poza domem (z wyłączeniem zajęć związanych z pracą), czasem wolnym;

- wykonywanie prac domowych: przygotowywanie posiłków i zmywanie naczyń, sprzątanie mieszkania, pranie i prasowanie, szycie, cerowanie, naprawa odzieży i obuwia, robótki na drutach, reperacja i odnawianie sprzętu i urządzeń, drobne remonty i naprawy mieszkań i obejścia, sprzątanie obejścia, usuwanie śniegu, ogrzewanie itp., opieka nad osobami dorosłymi chorymi i niedołężnymi, opieka nad dziećmi, w tym wszystkie rodzaje zajęć (higiena, wychowanie, pomoc w lekcjach, gry i inne zabawy itd.);

- zajęcia poza domem: zakupy (wszystkich rodzajów), pozostałe zajęcia poza domem (w tym korzystanie z usług w służbie zdrowia) ${ }^{11}$.

Prowadzone kalkulacje w tym zakresie nakierowane są na ustalanie budżetów (ilości czasu) przeznaczanego na poszczególne czynności. Należy pamiętać, że czas wolny to część budżetu czasu ${ }^{12}$.

Czas rozbija się na fragmenty, kiedy zakłada się, że na wykonanie wszystkich czynności nie ma wystarczającej jego ilości. Konieczne jest wtedy ustalenie systemu przydzielania czasu wybranym działaniom. Przed tym problemem stoją między innymi szkoły. Propozycje tego, czego należy w szkole nauczać nawzajem ze sobą konkurują, a liczba przedmiotów, które należałoby włączyć do programu szkolnego jest znacznie większa, niż dostępny czas. Stąd też jest on dobrem deficytowym, które należy w racjonalny sposób wydzielać i nim zarządzać. To, jak racjonowany i zarządzany jest czas, może dostarczyć wglądu w to, co się w szkole dzieje i jak ona funkcjonuje ${ }^{13}$.

Warto zaznaczyć, że problematyka zarządzania czasem w szkole w ramach jego budżetu stała się obecna w badaniach Zbigniewa Kwiecińskiego. Przyjrzał się on strukturze wykorzystania czasu poszczególnych lekcji, wyodrębniając czas sprzyjający rozwojowi ucznia, czas zorganizowany (nieszkodliwy dla ucznia) oraz czas stracony dla ucznia ${ }^{14}$. Wyniki badań prezentuje rycina 1, na której uwidacznia się swoista tendencja - w strukturze czasowej wszystkich, nawet najlepiej ocenionych, lekcji występują znaczące elementy czasu straconego.

Na podstawie zdecydowanej większości lekcji można wyprowadzić prostą generalizację, że uczęszczanie do szkoły (w świetle przytaczanych wyników badań), to przede wszystkim strata czasu, w drugiej kolejności jest mało wartościową formą spędzania czasu, a w stopniu wręcz marginalnym

11 Por. Z. Kwieciński, Budżet czasu uczniów; M. Czerepaniak-Walczak, Od próżniaczenia do zniewolenia; J. Pięta, Pedagogika.

12 M. Czerepaniak-Walczak, Od próżniaczenia do zniewolenia, s. 222.

13 R. Meighan, Socjologia edukacji, Torun 1993, s. 99-100.

14 Z. Kwieciński, Pedagogie postu. Preteksty - konteksty - podteksty, Kraków 2014, s. 241-242. 


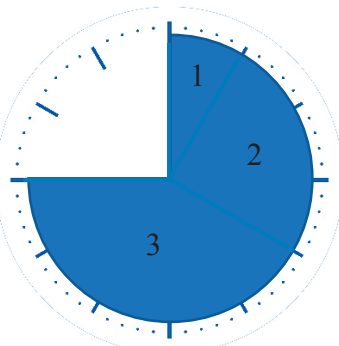

ogółem

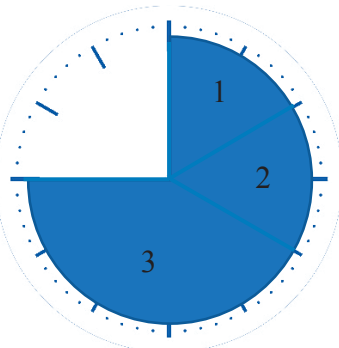

fizyka

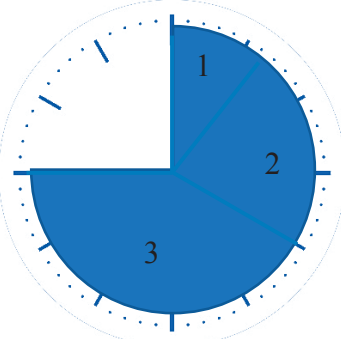

historia

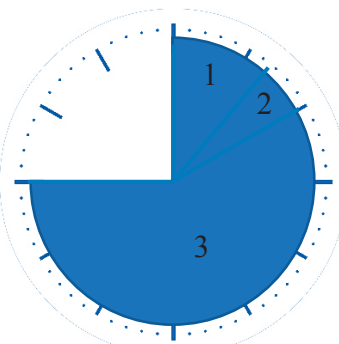

j. polski

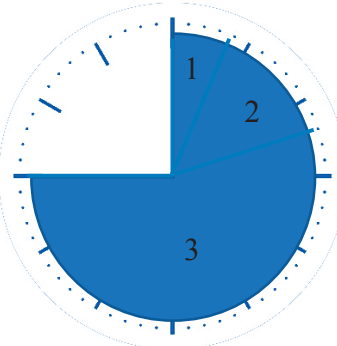

biologia

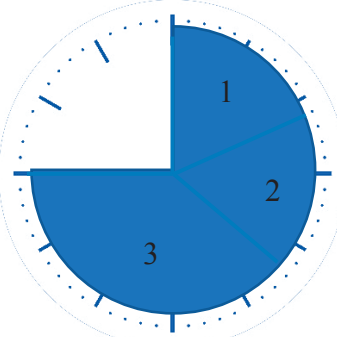

wiedza o społeczeństwie

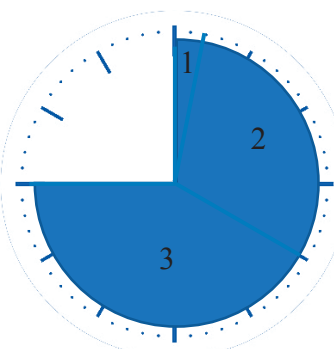

matematyka

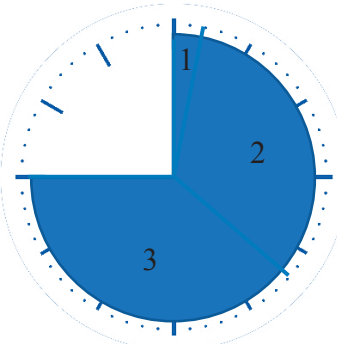

chemia

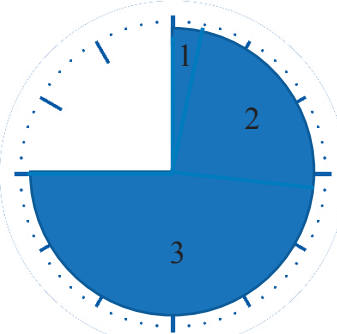

geografia

Ryc. 1. "Zegary" wykorzystania czasu wybranych lekcji dla rozwoju uczniów 1 - czas sprzyjający rozwojowi ucznia, 2 - czas zorganizowany, nieszkodliwy, 3 - czas całkowicie stracony dla ucznia

Źródło: Z. Kwieciński, Pedagogie postu. Preteksty - konteksty - podteksty, Kraków 2014, s. 246

- czasem poznawczo pożytecznym dla rozwoju uczniów ${ }^{15}$. Skoro czas można dobrze wykorzystać, zaoszczędzić, stracić, czy marnować, to można

15 Tamże, s. 245-249. 
go również ukraść ${ }^{16}$. Czy można zatem powiedzieć, że czas całkowicie stracony dla ucznia będzie czasem mu ukradzionym?

Ireneusz Kawecki pisze, że zarówno potoczna obserwacja życia klas szkolnych, jak i badania empiryczne pokazują istotne znaczenie czasu w kształceniu. Analizy wykazały, że uczniowie tych nauczycieli, którzy efektywniej dysponują posiadanym czasem lekcyjnym uczą się więcej w porównaniu z uczniami nauczycieli nie wykazujących takiej dbałości o czas. Innym wnioskiem jest to, że wielu nauczycieli nie uświadamia sobie, jak często i w jakiej ilości bezpowrotnie tracą czas przeznaczony na nauczanie, co powoduje, że rzeczywista ilość czasu efektywnie wykorzystywana przez nauczycieli różni się znacznie od siebie. Wyniki licznych badań, przedmiotem których było faktyczne wykorzystanie czasu lekcyjnego, wskazują, że w konkretnych warunkach szkolnych mamy do czynienia z kilkoma rodzajami czasu, którym dysponuje nauczyciel (prezentuje je tabela 1). Badania wykazały także, że ilość czasu przeznaczonego na kształcenie (biorąc pod uwagę szczególnie współudział uczniów w realizacji lekcji i osiągane przez nich sukcesy) podlega dużym wahaniom u różnych nauczycieli i w różnych placówkach, co ujawnia prawidłowość, zgodnie z którą im większe zaangażowanie uczniów i im większe ich powodzenie w uczeniu się, tym wyższa efektywność uczenia się. Dlatego nie wystarczy stwarzać uczniom okazji do uczenia się i przeznaczać na nie określoną ilość czasu, lecz także przygotować treści kształcenia na odpowiednim poziomie trudności, nadawać odpowiednie tempo uczeniu się, czy aktywizować uczniów, aby systematycznie odczuwali satysfakcję z własnych osiągnięć ${ }^{17}$. Innymi słowy, czas przeznaczony na opracowanie tematu

Kategorie czasu w klasie szkolnej

Tabela 1

\begin{tabular}{|l|l|}
\hline \multicolumn{1}{|c|}{ Kategorie czasu } & \multicolumn{1}{c|}{ Charakterystyka } \\
\hline Planowany & $\begin{array}{l}\text { czas przewidziany przez nauczyciela na realizację określonych } \\
\text { treści bądź tematu }\end{array}$ \\
\hline Przydzielony & $\begin{array}{l}\text { czas przeznaczony na naukę po wykonaniu przez nauczyciela } \\
\text { wszystkich czynności porządkowych i administracyjnych }\end{array}$ \\
\hline Zajęty & czas, który spędza uczeń wykonując dane działanie lub zadanie \\
\hline Wykorzystany & $\begin{array}{l}\text { czas, który uczeń wykorzystuje poprawnie, wykonując przy- } \\
\text { dzielone zadanie dydaktyczne }\end{array}$ \\
\hline Oczekiwania & $\begin{array}{l}\text { czas nauczycielskiego odpytywania, dyskusji, czy prezentacji } \\
\text { uczniowskich }\end{array}$ \\
\hline
\end{tabular}

Źródło: I. Kawecki, Wprowadzenie do wiedzy o szkole i nauczaniu, Kraków 2003, s. 66.

${ }^{16}$ G. Lakoff, Kobiety, ogień i rzeczy niebezpieczne. Co kategorie mówia nam o umyśle, Kraków 2011, s. 206-207.

${ }^{17}$ I. Kawecki, Wprowadzenie do wiedzy o szkole i nauczaniu, Kraków 2003, s. 65-68. 
w połączeniu ze skutecznym jego wykorzystaniem przesądza o efektywności nauczania. W tym aspekcie należy dostrzec, że ważniejsze jest to, co nauczyciel i uczniowie robią w czasie, który mają do dyspozycji, niż fizyczna ilość czasu $^{18}$.

Jednakże, utrzymywanie na najwyższym poziomie zaangażowania uczniów w trakcie procesu uczenia się jest bardzo wymagającym zadaniem dla nauczyciela. Charakteryzując zagadnienie czasu w kształceniu, trzeba zwrócić uwagę na znaczenie czasu oczekiwania, z którym mamy do czynienia podczas nauczycielskiego odpytywania, dyskusji, czy prezentacji uczniowskich. Czas oczekiwania stanowi różnicę pomiędzy końcem pytania zadanego przez nauczyciela a momentem wywołania ucznia do odpowiedzi. Zatem, jest to czas, odnośnie którego nauczyciel może sensownie zakładać, że wtedy właśnie uczniowie myślą o pytaniu, ponieważ przygotowują odpowiedź. Tutaj pojawia się kolejny aspekt temporalnego wymiaru lekcji - kontrola nad czasem. Nauczyciele zwykle czekają około 0,8 sekundy pomiędzy zadaniem pytania a wywołaniem ucznia, który ma udzielić odpowiedzi. Uczeń nie ma prawa do skorzystania $\mathrm{z}$ trochę dłuższego czasu na namysł. Kiedy jednak okres oczekiwania wynosiłby około 3 sekund (niektórzy badacze mówią o 3-5 sekundach), wówczas uaktywnia się wiele pozytywnych zjawisk, na przykład: uczniowie mają więcej czasu na przygotowanie odpowiedzi; mogą przedstawić alternatywne, lecz poprawne odpowiedzi; mniejsza liczba uczniów udziela niepoprawnych odpowiedzi; uczniowie wykazują większą pewność siebie; budują odpowiedzi, opierając się na wyższych poziomach myślenia. Z drugiej strony, sytuacja taka nie ma żadnych negatywnych konsekwencji. Stosowanie dłuższej przerwy wydaje się jednak trudne, zwłaszcza tym nauczycielom, którzy spieszą się do realizacji kolejnych zagadnień. W miarę jednak nabierania praktyki, sięganie po czas oczekiwania staje się łatwiejsze i przynosi znaczące korzyści ${ }^{19}$.

Ciekawie na tym tle prezentują się badania Renaty Wawrzyniak-Beszterdy, która analizowała doświadczenia komunikacyjne licealistów w czasie lekcji (ryc. 2). Wyniki pokazują, że prawie 60\% uczniów nigdy lub bardzo rzadko mieli poczucie prawa do dysponowania czasem rozmowy podczas lekcji, a zaledwie $20 \%$ raczej często lub zawsze posiadali takie poczucie ${ }^{20}$. Jest to wynik „klasycznego" sposobu traktowania czasu, gdzie nauczyciel występuje jako jego dysponent i strażnik ${ }^{21}$.

${ }^{18}$ D. Pankowska, T. Sokołowska-Dzioba, Skuteczna edukacja szkolna w kontekście zadań nauczyciela-wychowawcy, Lublin 2015, s. 65-69.

${ }_{19}$ I. Kawecki, Wprowadzenie do wiedzy, s. 65-68.

${ }^{20}$ R. Wawrzyniak-Beszterda, Doświadczenia komunikacyjne uczniów w czasie lekcji. Studium empiryczne, Kraków 2002, s. 72.

${ }^{21}$ I. Kawecki, Etnografia i szkoła, Kraków 1996, s. 88-89. 


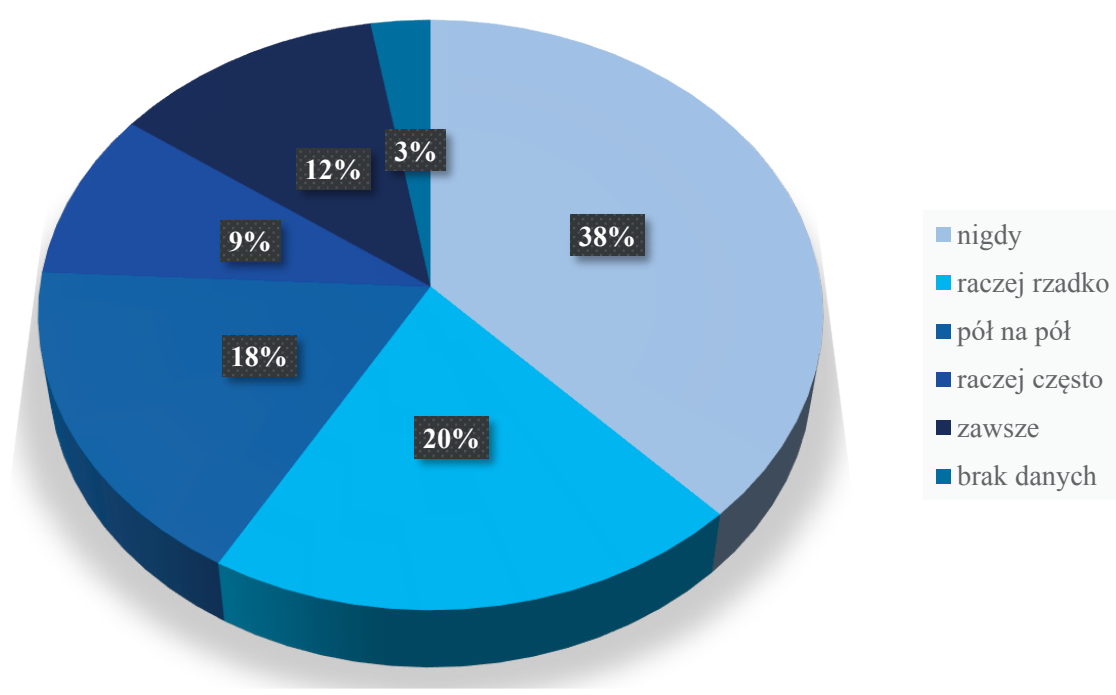

Ryc. 2. Poczucie prawa ucznia do kontrolowania czasu rozmowy

Źródło: R. Wawrzyniak-Beszterda, Doświadczenia komunikacyjne uczniów w czasie lekcji. Studium empiryczne, Kraków 2002, s. 72

Współcześnie w pedagogice można wyróżnić strukturalne, funkcjonalne oraz atrybutywne definicje czasu wolnego. W pierwszym rodzaju definicji wymieniane są postaci wykonywanych w czasie wolnym czynności (np. czas wolny to część budżetu czasu, która nie jest zajęta przez jakąkolwiek formę pracy zarobkowej, przez systematyczne kształcenie się, przez zaspokajanie elementarnych potrzeb fizjologicznych lub przez stałe obowiązki domowe. Może być ona jednak spożytkowana na swobodne wczasowanie bądź na życie rodzinne, obowiązki społeczne i aktywność przynoszącą doraźne korzyści). Definicje funkcjonalne charakteryzują się wyszczególnianiem tego, czemu służy lub służyć może czas wolny ${ }^{22}$ (np. czas wolny służy doskonaleniu osobowości oraz przywracaniu i utrzymywaniu równowagi psychofizycznej $\mathrm{w}$ organizmie człowieka ${ }^{23}$ ). $\mathrm{W}$ ostatnim rodzaju definicji zawierają się osobliwe atrybuty wolnego czasu, czyli takie, które są specyficzne i wyłączne dla tego czasu. W tym ujęciu czas wolny jest definiowany zawsze jako czas pojedynczego człowieka i odnosi się do tego, co czyni osoba oraz co się z nią dzieje. Jest swoistym przejawem antropocentryzmu, wyznaczającego podmiotową perspektywę opisu, interpretacji, wyjaśniania i projektowania tej sfery

${ }_{22}$ M. Czerepaniak-Walczak, Od próżniaczenia do zniewolenia, s. 222.

${ }^{23}$ Tamże, s. 29-30. 
życia, pozostając przy tym w powiązaniu z elementami podmiotowego świata życia ${ }^{24}$ (np. czas wolny, jako sfera życia w największym stopniu kierowania osobistymi potrzebami, dyspozycjami, nawykami, akceptowanymi wzorami postępowania oddziałuje na sfery pozostałe i jest przez nie kształtowany ${ }^{25}$ ).

Wydaje się, że badacze edukacji mogą nie dostrzegać całego potencjału czasu jako kategorii analitycznej. Na podstawie lektury podejść teoretycznych do tego fenomenu, poczynionych we wcześniejszych akapitach tej pracy, można wywnioskować, że czas reakcji i czas wolny stanowią tylko mały ułamek możliwości eksploracyjnych, jakie na gruncie pedagogiki dostarcza analiza pojęcia czasu. Czas istnieje obiektywnie i subiektywnie, można go rozpatrywać w sposób ilościowy i jakościowy, może być miarą zmian i „ruchu" w edukacji, może uwidaczniać pewien rytm oraz cykle w życiu szkoły, można także analizować jego składowe: przeszłość, teraźniejszość, przyszłość oraz relacje między nimi. Jak pisze H. Kwiatkowska,

czas przeszły, przeżyty, osobiście doznany, uzewnętrznia się rekonstrukcją zdarzeń minionych, utrwala więc to, co było. Czas teraźniejszy wyznaczony aktualnością chwili, świeżością doznań, działa na rzecz zachowania status quo. Czas przyszły, jako że jest wędrówką w nieznane, burzy dotychczasowe ustalenia, zmusza do projekcji nowej rzeczywistości, a tym samym zachowań innowacyjnych ${ }^{26}$.

Ta prawidłowość wymaga od człowieka umiejętnego korzystania z zasobów przeszłości na potrzeby teraźniejszości i przyszłości w celu planowania swojego dalszego rozwoju oraz konstruowania własnej tożsamości, która nie jest obecnie nadana (np. poprzez status urodzenia), ale zadana do wypracowania $^{27}$. Dlatego, dla pedagogiki ważne jest, aby jednostka została dobrze przygotowana do sprostania wyzwaniom współczesności związanym ze zjawiskiem nakładania się czasów ${ }^{28}$, które dotyczy człowieka będącego aktywnym na gruncie czasu teraźniejszego, ale funkcjonującym także w czasie przeszłym dzięki pamięci oraz czasie przyszłym, poprzez kreowanie wizji dalszego życia czy tworzenie bliższych lub dalszych perspektyw własnego „bycia”. Zatem, zadaniem pedagogiki staje się $\mathrm{w}$ tym przypadku wyposażenie jednostki w zestaw niezbędnej wiedzy, umiejętności i kompetencji, które pozwolą

${ }^{24}$ Tamże, s. 222.

${ }^{25}$ A. Zawadzka, K. Ferenz, Społeczne aspekty wypoczynku młodych kobiet, Wrocław 1998, s. 11.

${ }^{26}$ H. Kwiatkowska, Czas, miejsce, przestrzeń, s. 58.

${ }^{27}$ Por. Z. Bauman, Sztuka życia, Kraków 2012; tenże, Tożsamość ze spiżarni, tożsamość ze sklepu, [w:] Kultura popularna i (re)konstrukcje tożsamości, red. A. Gromkowska-Melosik, Poznań Leszno 2007.

${ }^{28}$ K. Majchrzak, O potencjale pamięci, [w:] Inspiracje pedagogia freinetowska, red. A. Semenowicz, H. Solarczyk, A. Szwech, t. I: Studia, źródła, wspomnienia dedykowane Halinie Semenowicz, Toruń 2014, s. 385-400. 
uświadomić, że przeszłość interpretowana jest przez pryzmat teraźniejszości, aktualnej (samo)świadomości ${ }^{29}$.

Omawiana kategoria zdaje się być jedną $\mathrm{z}$ ważniejszych $\mathrm{w}$ pedagogice, ponieważ wszystkie zdarzenia edukacyjne dzieją się w czasie. Czas je porządkuje, określa długość, szybkość, okres trwania zdarzeń oraz odstępy między nimi. Jednakże, czas w szkole nie jest jedynie pewną skalą pomiaru zdarzeń i procesów czy pewną ramą odniesienia. Jest on przede wszystkim immanentną właściwością zdarzeń i procesów społecznych, gdyż, zawarty w zdarzeniach, ma określone indywidualnie znaczenie i sens. Każda szkolna okoliczność (lekcja, apel, przerwa itp.) może mieć subiektywne, indywidualnie odbierane: trwanie (krótkie, długie), tempo (wolne, szybkie), rytm (stopniowy, chaotyczny) oraz znaczenie, gdyż może to być: czas pracy lub czas wolny, czas nasycony lub czas pusty ${ }^{30}$, czas ciekawy lub czas nudny ${ }^{31}$. Warto w tym miejscu wspomnieć, że badania z zakresu temporalnego wymiaru edukacji prowadzi między innymi Alicja Korzeniecka-Bondar, która wykorzystuje czas jako kategorię demaskującą na przykład pozór w szkole i podporządkowanie szkolnej codzienności. Przedmiotem swoich analiz czyni znaczenie i sens konkretnych wycinków roku szkolnego w powiązaniu z tym, co dzieje się wtedy na lekcjach i jakie to ma znaczenie dla rozwoju ucznia. Badaczka interesuje się także codziennością szkoły gimnazjalnej, rekonstruowaną przez nauczycieli $\mathrm{w}$ aspekcie ładu temporalnego oraz indywidualnymi definicjami doświadczanych przez nauczycieli sytuacji w kontekście temporalnego wymiaru prowadzonych przez nich działań ${ }^{32}$.

${ }^{29}$ Zob. J. Hudzik, Pamięć i czas w kulturze, filozofii i pedagogice: zarys zagadnienia w ujęciu hermeneutycznym, Gdańsk 2000.

30 "Czas pusty - czas «źle przeżywany» w wyniku braku «programu» na zagospodarowanie czasu wolnego - skutkuje często (...) funkcją szkodliwą"; cyt. za: M. Truszkowska-Wojtkowiak, Fenomen czasu wolnego, Gdańsk 2012, s. 252.

31 A. Korzeniecka-Bondar, Czas na pozór..., Studia Pedagogiczne, 2011, LXIV, s. 113; P. Sztompka, Socjologia zmian społecznych, Kraków 2005, s. 474-490.

${ }^{32}$ Zob. A. Korzeniecka-Bondar, Czas drukowania świadectw, czyli czerwcowy czas szkolny. O szkolnej grze pozorów, [w:] Młodzież - Kultura - Tożsamość, red. T. Bajkowski, K. Sawicki, Białystok 2012; taże, Oni wiedza o co chodzi..., czyli o dopasowywaniu jako narzędziu temporalnego porządkowania codzienności szkolnej, [w:] Światy życia codziennego uczestników interakcji wychowawczych. Eksploracje - analizy - interpretacje, red. A. Korzeniecka-Bondar, B. Tołwińska, U. Wróblewska, Zeszyty Naukowe Forum Młodych Pedagogów przy Komitecie Nauk Pedagogicznych Polskiej Akademii Nauk, 2012, 17; taże, Temporalne reżimy podtrzymujące codzienność szkolna nauczycieli gimnazjum, Przegląd Badań Edukacyjnych, 2016, 22; taże, Temporalne porządkowanie codzienności szkolnej w gimnazjum - perspektywa nauczycieli, Forum Oświatowe, 2015, 27(2); taże, Czas, s. 113; taże, O potrzebie ustanowienia sieci wspótdziałania pomiędzy życiem rodzinnym i zawodowym nauczycielek (analiza przy użyciu kategorii czasu), Chowanna, 2013, 41(2); taże, Lepsze to, niż zamulanie w domu? Krótka rzecz o wyćwiczeniu ucznia w kulturze pozoru, [w:] Sprawcy i/lub ofiary działań pozornych w edukacji szkolnej, red. M. Dudzikowa, K. Knasiecka-Falbierska, Kraków 2013; P. Sztompka, Socjologia. 
Ponieważ czas stanowi nieodłączny element każdego procesu uczenia się, wyznaczając nie tylko początek i koniec działań dydaktycznych (ale również określając warunki, w których realizowane są ich cele), należy przyjąć, iż opis każdego procesu edukacyjnego pozbawiony komponentu czasowości jest niekompletny ${ }^{33}$. Robert Kwaśnica zastanawia się, jak włączyć teraźniejszość do namysłu nad wychowaniem. Twierdzi, że podejmowanie takich właśnie prób, prowadzących do dyskursu poszukującego samowiedzy teraźniejszości, jest hermeneutycznym zadaniem pedagoga ${ }^{34}$.

W kontekście pedagogicznych badań realizowanych $\mathrm{w}$ podejściu biograficznym, czas staje się wyjściową kategorią analityczną. Eksploracji może być poddany sam fenomen czasu, jak również czas badań rozumiany jako zakotwiczenie badań w czasie (pamiętając, że są one zawsze umiejscowione w określonym czasie) ${ }^{35}$. Danuta Lalak pisze, że

istotą podejścia biograficznego jest specyficzny stosunek do czasu życia. Czas ludzkiego życia jest czymś niepowtarzalnym tak jak samo życie, ma zatem wymiar indywidualny, lecz sprzężony z czasem historycznym, społecznym. Czas jest wyznacznikiem wielu życiowych procesów o charakterze biologicznym (człowiek dojrzewa, starzeje się, umiera), osobistym (życie rodzinne, praca, związki, przyjaźnie, rozstania, sukcesy, porażki itp.), pokoleniowym (społeczne naznaczenie czasem historycznym, dlatego mówimy o pokoleniu „Kolumbów”, hippisów, „Solidarności”; JP II itp. ${ }^{36}$.

Elżbieta Dubas podkreśla niedostrzeganie kategorii czasu w badaniach biograficznych, szczególnie w andragogice. Autorka pisze, że

badaniu może być poddany czas sensu stricto (badanie fenomenu czasu), jak również czas badań (rozumiany jako zakotwiczenie badań w czasie, przy tym pamiętając, że badania zawsze umiejscowione są $\mathrm{w}$ określonym czasie). Jednak stosunkowo niewiele miejsca w biograficznych badaniach andragogicznych poświęca się właśnie czasowi. A przecież czas na swój sposób wytycza tory i nadaje kierunki badaniom biograficznym. Równocześnie istotnie "włącza się" w jednostkowe biografie. Czas - ta przestrzeń ludzkiego materialnego doświadczania wdziera się w zakamarki jednostkowego biegu życia, wypełniając je tworzywem obiektywnych doświadczeń oraz zarazem subiektywnością ich odbioru. Czas, choć trudny do uchwycenia (mimo zegarów, które próbują go mierzyć), jednak zdecydowanie określa charakter ludzkiego życia i ludzkich działań, nadając im wymiar egzystencjalny $(\ldots)^{37}$.

${ }^{33}$ K. Majchrzak, Kategoria czasu $w$ osadzonym $w$ badaniach $w$ działaniu procesie edukacyjnym zorientowanym na miejsca (żywej) pamięci, Edukacja Dorosłych, 2014, 2, s. 30.

${ }^{34}$ R. Kwaśnica, Teraźniejszość jako czas metafizyki, [w:] Poradnictwo w okresie transformacji kulturowej, red. A. Kargulowa, Wrocław 1995, s. 35.

${ }^{35}$ E. Dubas, Czas, biografia i badania biograficzne - różnorodność kontekstów w andragogicznej perspektywie, Edukacja Dorosłych, 2014, 2, s. 15.

36 D. Lalak, Życie jako biografia. Podejście biograficzne w badaniach pedagogicznych, Warszawa 2010, s. 119.

${ }^{37}$ E. Dubas, Czas, biografia, s. 15. 
Swoistym pomostem między różnymi wymiarami czasu są studia z zakresu historii oświaty, które rozpoznając przeszłość, wprowadzają jej spuściznę w teraźniejszość oraz w przyszłośćc ${ }^{38}$. Na drugim biegunie mamy do czynienia z projektowaniem edukacji, podnoszeniem kwestii jej przemian i wizjami szkoły przyszłości ${ }^{39}$.

Helena Ostrowicka temporalny wymiar edukacji, który uwidacznia się w szkole, lokuje w dyskursie młodości, który formułowany jest przez zespół stosunków zachodzących między: wyłanianiem się jednostkowych zróżnicowań uczniów, głównymi instancjami posiadającymi autorytet odgraniczania i wyszczególniania oraz opisem jednostek i schematów, w których oddziela się od siebie, łączy i klasyfikuje ludzi. Szkoła jest jedną z ważniejszych instytucji społecznych normalizujących kategoryzacje oparte na wieku kalendarzowym. Odwołując się do kategorii chronotopu (opisanej wcześniej), można zauważyć, że konstrukcje dojrzewania „w i poprzez czas” charakteryzuje relacja między czasem a przestrzenią ${ }^{40}$.

Chronotop dojrzewania organizuje „czas przygodowy”, z jego ukierunkowaniem na finał, dominującym wpływem czynników niezależnych od młodzieży (osób dorosłych, instytucji, „naturalnych” etapów rozwoju człowieka) oraz ahistorycznością i dekontekstualizacją. Czas przygodowy należy do wielkich, typologicznie trwałych czasoprzestrzeni. Poza tymi wielkimi całościami istnieją wartości czasoprzestrzenne o mniejszym stopniu i zakresie ${ }^{41}$.

Sekwencyjność (linearność), jak i cykliczność (rytm), jako sposób postrzegania, periodyczność czasu wydaje się ciekawą kategorią do opisu szkolnej codzienności. Rzeczywistość szkolna dzięki sekwencjom i cyklom podtrzymuje pewien porządek, który można nazwać ładem temporalnym. Można go zdefiniować jako sieć temporalnych relacji poszczególnych osób, obejmują-

38 Tamże.

39 Zob. S. Dylak, Architektura wiedzy o szkole, Warszawa 2013; K. Denek, Edukacja dziś - jutro, Leszno - Poznań - Żary 2006; tenże, Ku dobrej edukacji, Toruń 2005; B.D. Gołębniak, Zmiany edukacji nauczycieli. Wiedza - biegłość - refleksyjność, Torun - Poznań 1998; M. Dudzikowa, Mit o szkole jako miejscu wszechstronnego rozwoju ucznia, Kraków 2001; D. Klus-Stańska, Ciągłość i zmiana czy bierność i niekontrolowane odruchy - w którym kierunku zmierza szkoła? [w:] Ciagłość $i$ zmiana w edukacji szkolnej - społeczne $i$ wychowawcze obszary napięć, red. J. Surzykiewicz, M. Kulesza, Łódź 2010; S. Jabłoński, J. Wojciechowska, Wizja szkoły XXI wieku: kluczowe kompetencje nauczyciela a nowa funkcja edukacji, Studia Edukacyjne, 2013, 27, s. 43-63; A.I. Brzezińska, B. Ziółkowska, Przed jakimi wyzwaniami stoi dzisiaj szkoła? Studia Edukacyjne, 2013, 27, s. 29-42; E. Januszewska i in., W poszukiwaniu teorii szkoły, Pedagogika Społeczna, 2015, 3(57), s. 89-112; I. Nowosad, Perspektywy rozwoju szkoły. Szkice z teorii szkoły, Warszawa 2003; J. Kuźma, Nauka o szkole. Teorie i wizje przyszłej szkoły, Roczniki Pedagogiczne, 2013, 2; Z. Wieczorek, Przyszłość edukacji czy edukacja bez przyszłości? Edukacja i Dialog, 2001, 4(127); A. Nalaskowski, Edukacja, która nie chce przeminąć, Kraków 1999.

40 H. Ostrowicka, Urządzanie młodzieży. Studium analityczno-krytyczne, Kraków 2015, s. 111.

41 Tamże, s. 126. 
cą ciągłe przystosowania i koordynację wysiłków, by praca była właściwie zorganizowana. Organizacja pracy w szkole jest procesem dynamicznym, będącym wypadkową ciągłego interpretowania i definiowania sytuacji przez uczestników procesu kształcenia. W tej płynnie zmieniającej się rzeczywistości, działania poszczególnych osób muszą być prawidłowo zharmonizowane. Dotyczy to zarówno planów pracy, jak i terminów jej wykonania. Uczestnicy interakcji wychowawczych w codziennym funkcjonowaniu uzgadniają między sobą plany dotyczące wielu kwestii: długości trwania i przerw w działaniach, ich tempa, rytmu, terminów realizacji, punktualności rozpoczynania i kończenia. W szkole sekwencje czynności uczniów i nauczycieli muszą być zsynchronizowane w czasie, tak w wymiarze całego roku szkolnego, jak i poszczególnych lekcji ${ }^{42}$.

Zamiast podsumowania warto odwołać się do słów Jadwigi Staniszkis, która pisze o potrzebie ontologizacji czasu, czyli traktowania tego fenomenu jako elementu bytu. Badaczka wnosi o przyjęcie nowej definicji czasu, konsekwencją czego byłoby uznanie, że różne obszary ludzkiej aktywności rządzą się odmiennymi formami temporalnej strukturyzacji zjawisk występujących $\mathrm{w}$ ich granicach ${ }^{43}$. Powyższy postulat został zrealizowany $\mathrm{w}$ analizie transakcyjnej, a jego odzwierciedlenie można odnaleźć w koncepcji strukturalizacji czasu. Analiza transakcyjna to koncepcja osobowości i systematycznej psychoterapii służąca osobistemu rozwojowi i zmianie ${ }^{44}$. Opiera się ona przede wszystkim na spójnej koncepcji psychologicznej, będącej podstawą oddziaływań terapeutycznych ${ }^{45}$ autorstwa Erica Berne'a, amerykańskiego psychiatry i psychoterapeuty. Według Berne'a, celem AT staje się stworzenie jak najbardziej otwartej i możliwie autentycznej komunikacji pomiędzy emocjonalnymi i intelektualnymi strukturami osobowości ludzkiej. Tylko wtedy człowiek zdolny jest do jednoczesnego wykorzystywania uczuć i umysłu ${ }^{46}$. Zatem, analiza transakcyjna przypisuje sobie zasługę wykrycia oraz stawia cel dalszego wykrywania niektórych z praw i regularności funkcjonowania ludzkiej psychiki ${ }^{47}$. Aby to osiągnąć, AT jest podzielona na cztery komplementarne obszary i obejmuje: analizę struktury osobowości (transakcyjnych stanów Ja), analizę strukturalizacji czasu (w tym gier transakcyjnych), analizę transakcji (nazwaną inaczej analizą właściwą) oraz analizę skryptu (ukrytego scenariu-

\footnotetext{
${ }^{42}$ A. Korzeniecka-Bondar, Temporalne porzadkowanie, s. 105.

${ }^{43}$ J. Staniszkis, Wtadza globalizacji, Warszawa 2004.

${ }^{44}$ J. Jagieła, Stownik analizy transakcyjnej, Częstochowa 2012, s. 24.

45 D. Pankowska, Analiza transakcyjna w edukacji czy edukacyjna analiza transakcyjna - próba porządkowania znaczeń, Edukacyjna Analiza Transakcyjna, 2012, 1, s. 13.

${ }^{46}$ M. James, D. Jongeward, Narodzić się, by wygrać. Analiza transakcyjna na co dzień, Poznań 1994, s. 35-37.

${ }^{47}$ T. Harris, Ja jestem OK - ty jesteś OK. Praktyczny przewodnik po analizie transakcyjnej, Poznań 2009, s. 36.
} 
sza życia jednostek i zbiorowości $)^{48}$. Drugie z wymienionych pól badawczych może zostać wykorzystane $\mathrm{w}$ badaniach nad czasem $\mathrm{w}$ pedagogice, aby na przykład dokonać analizy sieci temporalnych relacji poszczególnych osób w szkole.

$\mathrm{W}$ analizie transakcyjnej czas jest połączony z relacjami interpersonalnymi, gdyż w myśl założeń tej koncepcji, tym, co pozwala zaspokoić istotne potrzeby człowieka jest kontakt z innymi ludźmi. Stąd też każdy człowiek wypełnia swoje życie relacjami z otoczeniem społecznym. Może to być kontakt fizyczny, na przykład dotyk (podanie ręki na powitanie, poklepanie po ramieniu w celu pocieszenia). Może on również przybierać charakter symboliczny, wyrażony słowem, gestem, spojrzeniem lub innym działaniem. Takie rzeczywiste bądź symboliczne działania, dające człowiekowi pewność, że jest dostrzegany przez innych ${ }^{49}$. Taki akt uznania obecności i bycia zauważonym przez innych ludzi ${ }^{50}$ cechuje się różną intensywnością w strukturalizacji czasu, dlatego w zależności od rodzaju i jakości interakcji międzyludzkich ${ }^{51}$ można wyróżnić siedem sposobów strukturalizowania czasu:

- wycofanie - jest skrajnym, granicznym przypadkiem, w którym ludzie jawnie się nie komunikują̨25; polega ono na tym, że człowiek izoluje się poprzez fizyczne odejście bądź poprzez wyłączenie się psychiczne i pozostawanie ze swoimi myślami ${ }^{53}$; wycofywanie się, choć nie jest relacją między dwiema osobami, występuje często w układach społecznych ${ }^{54}$;

- rytuały - najbezpieczniejszy rodzaj zachowań społecznych, które są mniej lub bardziej formalnymi, stylizowanymi sposobami komunikowania się, mogącymi przerodzić się $\mathrm{w}$ ceremonie o przewidywalnym przebiegu ${ }^{55}$; przybierają formę relacji prostych i stereotypowych, zapewniających dobre funkcjonowanie w towarzystwie ${ }^{56}$; rytuał jest społecznie zaplanowanym sposobem wykorzystania czasu, w którym wszyscy zgadzają się robić to samo;

48 J. Jagieła, Edukacyjna analiza transakcyjna w kilku odstonach, Częstochowa 2012, s. 13; taże, Transactional analysis (TA) as a way of improving the interpersonal competence of teachers in the twenty first century, [w:] The quality of education in the light of educational challenges and tendencies of the third millennium, red. A. Kozłowksa, B. Kožuh, Częstochowa 2001, s. 84.

${ }^{49}$ M. James, D. Jongeward, Narodzić się, by wygrać, s. 72-75.

${ }^{50}$ J. Jagieła, Edukacyjna analiza transakcyjna, s. 210.

${ }^{51}$ D. Pankowska, Nauczyciel w perspektywie analizy transakcyjnej, Lublin 2001, s. 62-63; L. Cowles-Boyd, H.S. Boyd, Play as a Time Structure, Transactional Analysis Journal, 1980, 10, 1, s. 5-7; A. Mokrzycka, Zabawa jako dodatkowa kategoria strukturalizacji czasu, Edukacyjna Analiza Transakcyjna, 2015, 4, s. 89-99.

52 E. Berne, Dzień dobry... i co dalej? Poznań 2008, s. 42.

${ }_{53}$ M. James, D. Jongeward, Narodzić się, by wygrać, s. 88-89.

${ }^{54}$ T. Harris, Ja jestem OK - ty jesteś OK, s. 166.

${ }^{55}$ E. Berne, Dzień dobry, s. 42; J. Jagieła, Edukacyjna analiza transakcyjna, s. 22; taże, Stownik analizy transakcyjnej, s. 187.

${ }_{56}$ M. James, D. Jongeward, Narodzić się, by wygrać, s. 89-90. 
to bezpieczna forma strukturyzacji czasu, gdyż nie wymaga wchodzenia w żadne związki lub podejmowania zobowiązań wobec innych ludzi; jego zakończenie jest możliwe do przewidzenia i może być przyjemne, jeśli ktoś dotrzymuje kroku innym i zachowuje się prawidłowo ${ }^{57}$;

- rozrywki - rodzaj sondowania towarzyskiego, w którym ktoś pragnie zdobyć informacje o nowych znajomych w sposób niezobowiązujący i niezagrażający ${ }^{58}$; to proste relacje przejawiające się podczas rozmowy na różne błahe tematy ${ }^{59}$, wymiany dość ogólnych poglądów i opinii, opowiadania o przeszłych zdarzeniach czy plotkowanie ${ }^{60}$; to stosunkowo bezpieczne, a jednocześnie uprzejme rozmowy, które chętnie prowadzą zwłaszcza ci, którzy jeszcze niezbyt dobrze się znają ${ }^{61}$;

- prace - najbardziej powszechna, wygodna (interpersonalnie) i utylitarna forma strukturalizacji czasu, nastawiona na tworzenie planu działania w materii świata społecznego; $\mathrm{w}$ tym przypadku programowanie materialne jest skutkiem zetknięcia się człowieka ze zmiennością świata zewnętrznego ${ }^{62}$ i ma ścisły związek z realną rzeczywistością ${ }^{63}$, stąd w przypadku tej formy strukturalizacji czasu przebieg transakcji wyznacza materia, której praca (w znaczeniu transakcyjnym) dotyczy;

- zabawy - stosunkowo niedawno wyodrębniona i dodana forma przez Laurę Cowles-Boyd oraz Harry S. Boyda ${ }^{64}$; definiowane są jako seria trwałych relacji (o jawnych motywach), w których występują głównie pozytywne komunikaty, a efektem są pozytywne emocje; cechuje je pełna kreatywność, ekspresja i spontaniczność. Zapewniają powstawanie prawdziwych emocji, takich jak radość oraz spontaniczności na poziomie społecznym ${ }^{65}$. Są one także przyczyną wielu przyjemnych doznań, np. fantazjowanie, świętowanie, sport, hobby ${ }^{66}$;

- gry - stanowią serię komunikatów o ukrytych motywach prowadzących do dobrze określonego, z góry przewidzianego wyniku ${ }^{67}$; nie mają nic wspólnego z pierwotnymi zabawami dziecka, są następstwem utajonych zamiarów

${ }_{57}$ T. Harris, Ja jestem OK - ty jesteś OK, s. 166-167; J. Jagieła, Edukacyjna analiza transakcyjna, s. 22; taże, Stownik analizy transakcyjnej, s. 187.

${ }_{58}$ T. Harris, Ja jestem OK - ty jesteś OK, s. 168-169.

59 R. Rogoll, Aby być sobą. Wprowadzenie do analizy transakcyjnej, Warszawa 1989, s. 52.

${ }^{60}$ D. Pankowska, Nauczyciel w perspektywie, s. 63-64.

${ }^{61}$ R. Rogoll, Aby być soba, s. 52.

${ }^{62}$ E. Berne, W co grają ludzie? Psychologia stosunków międzyludzkich, Warszawa 2000, s. 42-43.

${ }^{63}$ R. Rogoll, Aby być soba, s. 52.

${ }^{64}$ A. Mokrzycka, Zabawa jako dodatkowa kategoria, s. 89-99.

${ }^{65}$ L. Cowles-Boyd, H.S. Boyd, Play as a Time Structure, s. 7-9; J. Jagieła, Stownik analizy transakcyjnej, s. 262.

${ }_{66}$ J. Jagieła, Stownik analizy transakcyjnej, s. 262; taże, Edukacyjna analiza transakcyjna, s. 23.

67 J. Jagieła, Edukacyjna analiza transakcyjna, s. 22; taże, Stownik analizy transakcyjnej, s. 77; E. Berne, W co grają ludzie? s. 37-38. 
w relacjach, które zewnętrznie wydają się słuszne, jednak w rzeczywistości są podporządkowane ukrytym i nieszczerym, ciągle powtarzającym się motywom ${ }^{68}$;

- intymność - najatrakcyjniejsza forma kontaktu społecznego ${ }^{69}$ i graniczny sposób strukturalizacji czasu ${ }^{70}$, w której występuje „dawanie" i „branie” bez wzajemnego wykorzystywania ${ }^{71}$; to otwarty, uczciwy i charakteryzujący się wzajemnym, wolnym od wykorzystywania, niewymuszonym dzieleniem $\mathrm{się}^{72}$, empatią, czułością i poczuciem bliskości ${ }^{73}$ stosunek międzyludzki nie wykorzystujący gier ${ }^{74}$ i wyrażający prawdziwe uczucia, myśli i doświadczenia zaangażowanych w niego osób.

Wydaje się, że strukturalizacja czasu w analizie transakcyjnej jest nowym sposobem temporalnej konceptualizacji relacji międzyludzkich panujących w rozmaitych instytucjach (także edukacyjnych). Jest to jedna z wielu możliwości wykorzystania potencjału drzemiącego w kategorii analitycznej, jaką jest właśnie czas. To on, będący osobliwym i fascynującym zjawiskiem, jest podstawowym absolutem rzeczywistości i ludzkiego poznania. Człowiek jest w nim zanurzony, a każde jego doświadczenie (indywidualne czy społeczne) jest kategoryzowane $w$ ramach czasowych, pozwalających realizować porządek, spójność i znaczenie w sferze zdarzeńt5. Co więcej, każdy wytwór człowieka ma swój czasowy charakter, włączając w to różne instytucje społeczne, których temporalny wymiar uwidacznia się w dynamice ich funkcjonowania i relacjach międzyludzkich $\mathrm{w}$ nich panujących. Pojęcie czasu najczęściej nie jest zwerbalizowane, a nawet uświadamiane i znajduje wyraz raczej w działaniu aniżeli w słowie, dlatego wymaga szczególnych zabiegów badawczych. Z racji swej "oczywistości”, "zwykłości” czy "naturalnego" wbudowania w codzienność jest szczególnie trudnym i opornym przedmiotem analiz, które wymaga znalezienia właściwych perspektyw teoretycznych i opracowania narzędzi badawczych czyniących je problematycznym ${ }^{76}$. To może być główna trudność, jaką napotykają badacze rzeczywistości społecznej rozpatrywanej przez pryzmat czasu. Kategoria ta jest natomiast bardzo pojemna i wieloaspektowa. Uwidacznia się to także w edukacji. Procesy rozwojowe, które

${ }^{68}$ R. Rogoll, Aby być soba, s. 52-53.

${ }^{69}$ E. Berne, $W$ co graja ludzie? s. 12.

${ }^{70}$ E. Berne, Dzień dobry, s. 44-45.

${ }^{71}$ R. Rogoll, Aby być soba, s. 53-54.

${ }^{72}$ E. Berne, Dzień dobry, s. 44-45.

${ }^{73}$ M. James, D. Jongeward, Narodzić się, by wygrać, s. 92-94.

${ }^{74}$ E. Berne, Dzień dobry, s. 44-45.

${ }^{75}$ A. Bańka, Typy tożsamości wczesnej dorostości z perspektywy orientacji czasowej preferowanych stylów życia, [w:] Czas w życiu człowieka, red. K. Popiołek, A. Chudzicka-Czupała, Katowice 2010, s. 103.

${ }^{76}$ E. Tarkowska, Czas w życiu Polaków. Wyniki badań, hipotezy, impresje, Warszawa 1992, s. 12. 
przebiegają w środowisku wychowawczym, w relacjach wychowawczych, czy w oddziaływaniach podmiotów socjalizacyjnych, dokonują się w kontekście i obszarze swego rodzaju sprzężenia, które zawarte jest w temporalnym wymiarze, a ten z kolei jest nośnikiem następującego rozwoju ${ }^{77}$.

\section{BIBLIOGRAFIA}

Augustyn Św., Wyznania, przekł. Z. Kubiak, Wydawnictwo Znak, Kraków 1994.

Bańka A., Typy tożsamości wczesnej dorostości z perspektywy orientacji czasowej preferowanych stylów życia, [w:] Czas w życiu człowieka, red. K. Popiołek, A. Chudzicka-Czupała, Wydawnictwo Uniwersytetu Śląskiego, Katowice 2010.

Bauman Z., Tożsamość ze spiżarni, tożsamość ze sklepu, [w:] Kultura popularna i (re)konstrukcje tożsamości, red. A. Gromkowska-Melosik, Wyższa Szkoła Humanistyczna, Poznań Leszno 2007.

Bauman Z., Sztuka życia, Wydawnictwo Literackie, Kraków 2012.

Berne E., W co grają ludzie? Psychologia stosunków międzyludzkich, Wydawnictwo Naukowe PWN, Warszawa 2000.

Berne E., Dzień dobry... i co dalej? Dom Wydawniczy Rebis, Poznań 2008.

Brzezińska A.I., Ziółkowska B., Przed jakimi wyzwaniami stoi dzisiaj szkoła? Studia Edukacyjne, 2013, 27.

Cowles-Boyd L., Boyd H.S., Play as a Time Structure, Transactional Analysis Journal, 1980, $10,1$.

Czerepaniak-Walczak M., Od próżniaczenia do zniewolenia - w poszukiwaniu dyskursów czasu wolnego, [w:] Pedagogika społeczna, red. E. Marynowicz-Hetka, Wydawnictwo Naukowe PWN, Warszawa 2009.

Denek K., Ku dobrej edukacji, Wydawnictwo Edukacyjne Akapit, Toruń 2005.

Denek K., Edukacja dziś - jutro, Wydawnictwo WSH, Leszno - Poznań - Żary 2006.

Dubas E., Czas, biografia i badania biograficzne - różnorodność kontekstów w andragogicznej perspektywie, Edukacja Dorosłych, 2014, 2.

Dudzikowa M., Mit o szkole jako miejscu wszechstronnego rozwoju ucznia, Oficyna Wydawnicza Impuls, Kraków 2001.

Dylak S., Architektura wiedzy o szkole, Wydawnictwo Difin, Warszawa 2013.

Gołębniak B.D., Zmiany edukacji nauczycieli. Wiedza - biegłość - refleksyjność, Wydawnictwo Edytor, Torun - Poznań 1998.

Gromkowska-Melosik A. (red.), Kultura popularna i (re)konstrukcje tożsamości, Wyższa Szkoła Humanistyczna, Poznań - Leszno 2007.

Harris T., Ja jestem OK - ty jesteś OK. Praktyczny przewodnik po analizie transakcyjnej, Dom Wydawniczy Rebis, Poznań 2009.

Hudzik J., Pamięć i czas w kulturze, filozofii i pedagogice: zarys zagadnienia w ujęciu hermeneutycznym, Wydawnictwo Uniwersytetu Gdańskiego, Gdańsk 2000.

Jabłoński S., Wojciechowska J., Wizja szkoty XXI wieku: kluczowe kompetencje nauczyciela a nowa funkcja edukacji, Studia Edukacyjne, 2013, 27.

77 P. Prüfer, Linearne i cykliczne procesy formacyjno-socjalizacyjne $w$ społeczeństwie i w środowisku akademickim a niepetnosprawność, [w:] Wielowymiarowość integracji społeczno-zawodowej studentów z niepetnosprawnościa, red. B. Szczupał, K. Kutek-Sładek, Kraków 2016, s. 145. 
Jagieła, J., Transactional analysis (TA) as a way of improving the interpersonal competence of teachers in the twenty first century, [w:] The quality of education in the light of educational challenges and tendencies of the third millennium, red. A. Kozłowksa, B. Kožuh, Wydawnictwo WSP, Częstochowa 2001.

Jagieła J., Edukacyjna analiza transakcyjna w kilku odsłonach, Wydawnictwo AJD, Częstochowa 2012.

Jagieła J., Stownik analizy transakcyjnej, Wydawnictwo AJD, Częstochowa 2012.

Jagieła J., Sarnat-Ciastko A., Dlaczego analiza transakcyjna. Rozmowy o zastosowaniu analizy transakcyjnej w pracy nauczyciela i wychowawcy, Wydawnictwo AJD, Częstochowa 2015.

James M., Jongeward D., Narodzić się, by wygrać. Analiza transakcyjna na co dzień, Dom Wydawniczy Rebis, Poznań 1994.

Januszewska E., Kulesza M., Kwiatkowski M., Odrowąż-Coates A., Perkowska-Klejman A., Wiatr M., W poszukiwaniu teorii szkoty, Pedagogika Społeczna, 2015, 3(57).

Kawecki I., Etnografia i szkoła, Oficyna Wydawnicza Impuls, Kraków 1996.

Kawecki I., Wprowadzenie do wiedzy o szkole i nauczaniu, Oficyna Wydawnicza Impuls, Kraków 2003.

Klus-Stańska D., Ciagłość i zmiana czy bierność i niekontrolowane odruchy - w którym kierunku zmierza szkoła? [w:] Ciagłość i zmiana wedukacji szkolnej - społeczne i wychowawcze obszary napięć, red. J. Surzykiewicz, M. Kulesza, Wydawnictwo UŁ, Łódź 2010.

Korzeniecka-Bondar A., Czas na pozór..., Studia Pedagogiczne, 2011, LXIV.

Korzeniecka-Bondar A., Czas drukowania świadectw, czyli czerwcowy czas szkolny. O szkolnej grze pozorów, [w:] Młodziė̇ - Kultura - Tożsamość, red. T. Bajkowski, K. Sawicki, Wydawnictwo Uniwersyteckie Trans Humana, Białystok 2012.

Korzeniecka-Bondar A., Oni wiedza o co chodzi..., czyli o dopasowywaniu jako narzędziu temporalnego porządkowania codzienności szkolnej, [w:] Światy życia codziennego uczestników interakcji wychowawczych. Eksploracje - analizy - interpretacje, red. A. Korzeniecka-Bondar, B. Tołwińska, U. Wróblewska, Zeszyty Naukowe Forum Młodych Pedagogów przy Komitecie Nauk Pedagogicznych Polskiej Akademii Nauk, 2012, 17.

Korzeniecka-Bondar A., Lepsze to, niż zamulanie w domu? Krótka rzecz o wyćwiczeniu ucznia w kulturze pozoru, [w:] Sprawcy i/lub ofiary działan pozornych w edukacji szkolnej, red. M. Dudzikowa, K. Knasiecka-Falbierska, Oficyna Wydawnicza Impuls, Kraków 2013.

Korzeniecka-Bondar A., O potrzebie ustanowienia sieci wspótdziałania pomiędzy życiem rodzinnym i zawodowym nauczycielek (analiza przy użyciu kategorii czasu), Chowanna, 2013, 41(2).

Korzeniecka-Bondar A., Temporalne porządkowanie codzienności szkolnej w gimnazjum - perspektywa nauczycieli, Forum Oświatowe, 2015, 27(2).

Korzeniecka-Bondar A., Temporalne reżimy podtrzymujące codzienność szkolnq nauczycieli gimnazjum, Przegląd Badań Edukacyjnych, 2016, 22.

Kuźma J., Nauka o szkole. Teorie i wizje przyszłej szkoły, Roczniki Pedagogiczne, 2013, 2.

Kwaśnica R., Teraźniejszość jako czas metafizyki, [w:] Poradnictwo w okresie transformacji kulturowej, red. A. Kargulowa, Wydawnictwo Uniwersytetu Wrocławskiego, Wrocław 1995.

Kwiatkowska H., Czas, miejsce, przestrzeń - zaniedbane kategorie pedagogiczne, [w:] Pedagogika u progu trzeciego tysiaclecia. Materiaty pokonferencyjne, red. A. Nalaskowski, K. Rubacha, Wydawnictwo Naukowe UMK, Torun 2001.

Kwieciński Z., Budżet czasu uczniów a ich środowisko, PWN, Warszawa 1979.

Kwieciński Z., Pedagogie postu. Preteksty - konteksty - podteksty, Oficyna Wydawnicza Impuls, Kraków 2014.

Kwilecki K., Rozważania o czasie wolnym. Wybrane zagadnienia, Górnośląska Wyższa Szkoła Handlowa im. Wojciecha Korfantego, Katowice 2011. 
Lakoff G., Kobiety, ogień i rzeczy niebezpieczne. Co kategorie mówia nam o umyśle, Wydawnictwo Universitas, Kraków 2011.

Lalak D., Życie jako biografia. Podejście biograficzne w badaniach pedagogicznych, Wydawnictwo Akademickie Żak, Warszawa, 2010.

Majchrzak K., Kategoria czasu w osadzonym w badaniach w działaniu procesie edukacyjnym zorientowanym na miejsca (żywej) pamięci, Edukacja Dorosłych, 2014, 2.

Majchrzak K., O potencjale pamięci, [w:] Inspiracje pedagogia freinetowska, tom I: Studia, źródła, wspomnienia dedykowane Halinie Semenowicz, red. A. Semenowicz, H. Solarczyk, A. Szwech, Wydawnictwo Naukowe UMK, Torun 2014.

Meighan R., Socjologia edukacji, Wydawnictwo Naukowe UMK, Toruń 1993.

Milerski B., Śliwerski B. (red.), Pedagogika. Leksykon PWN, Wydawnictwo Naukowe PWN, Warszawa 2000.

Mokrzycka A., Zabawa jako dodatkowa kategoria strukturalizacji czasu, Edukacyjna Analiza Transakcyjna, 2015, 4.

Nalaskowski A., Edukacja, która nie chce przeminąc, Oficyna Wydawnicza Impuls, Kraków 1999.

Nowosad I., Perspektywy rozwoju szkoły. Szkice z teorii szkoty, Instytut Badań Edukacyjnych, Warszawa 2003.

Ostrowicka H., Urządzanie młodzieży. Studium analityczno-krytyczne, Oficyna Wydawnicza Impuls, Kraków 2015.

Pankowska D., Nauczyciel w perspektywie analizy transakcyjnej, Wydawnictwo UMCS, Lublin 2001.

Pankowska D., Analiza transakcyjna w edukacji czy edukacyjna analiza transakcyjna - próba porządkowania znaczeń, Edukacyjna Analiza Transakcyjna, 2012, 1.

Pankowska D., Sokołowska-Dzioba T., Skuteczna edukacja szkolna w kontekście zadań nauczyciela-wychowawcy, Wydawnictwo UMCS, Lublin 2015.

Pater R., Czas wolny w (dla) edukacji kulturalnej dzieci, Edukacja Elementarna, 2015, 35.

Pięta J., Pedagogika czasu wolnego, Wydawnictwo FREI, Warszawa 2014.

Prüfer P., Linearne i cykliczne procesy formacyjno-socjalizacyjne w społeczeństwie $i$ w środowisku akademickim a niepetnosprawność, [w:] Wielowymiarowość integracji społeczno-zawodowej studentów z niepetnosprawnościa, red. B. Szczupał, K. Kutek-Sładek, Wydawnictwo Naukowe Uniwersytetu Papieskiego Jana Pawła II, Kraków 2016.

Przybysz A., Czas w pedagogice, [w:] Czas w życiu człowieka, red. K. Popiołek, A. Chudzicka-Czupała, Wydawnictwo Uniwersytetu Śląskiego, Katowice 2010.

Rogoll R., Aby być soba. Wprowadzenie do analizy transakcyjnej, Państwowe Wydawnictwo Naukowe, Warszawa 1989.

Stownik grecko-polski, red. Z. Abramowiczówna, PWN, Warszawa 1965.

Staniszkis J., Wtadza globalizacji, Wydawnictwo Naukowe Scholar, Warszawa 2004.

Sztompka P., Socjologia zmian społecznych, Wydawnictwo Znak, Kraków 2005.

Tarkowska E., Czas w życiu Polaków. Wyniki badań, hipotezy, impresje, Polska Akademia Nauk, Instytut Filozofii i Socjologii, Warszawa 1992.

Truszkowska-Wojtkowiak M., Fenomen czasu wolnego, Harmonia Universalis, Gdańsk 2012.

Wawrzyniak-Beszterda R., Doświadczenia komunikacyjne uczniów w czasie lekcji. Studium empiryczne, Oficyna Wydawnicza Impuls, Kraków 2002.

Wieczorek Z., Przyszłość edukacji czy edukacja bez przyszłości? Edukacja i Dialog, 2001, 4(127).

Zawadzka A., Ferenz K., Społeczne aspekty wypoczynku młodych kobiet, Wydawnictwo Uniwersytetu Wrocławskiego, Wrocław 1998. 